\title{
FREQUENCY, DIVERSITY AND ECOLOGICAL STRATEGIES OF EPIPHYTIC LICHENS IN THE SWISS CENTRAL PLATEAU AND THE PRE-ALPS
}

\author{
Michael DIETRICH^ ${ }^{\star}$ and Christoph SCHEIDEGGER`
}

\begin{abstract}
To identify representative quantitative criteria for the creation of a future Red List of epiphytic lichens, 849 trees in 132 long-term ecological observation plots in the Swiss Central Plateau and the Pre-Alps were surveyed by standard sampling. Based on the trees, frequency data of the lichen taxa observed are described by the $\log$ series model, indicating the controlling effect of few ecological factors. Based on the plots, four classes of scarcity, each comprising $25 \%$ of the species, were established. As a contribution to the development of a national, representative survey of lichens, $(\alpha$-diversity (species richness, species density) and $\beta$-diversity (dissimilarity) were calculated in terms of region, vegetation formation, regetation belt and for their combinations. Differences in lichen diversity between the Central Plateau and the Pre-Alps were caused by the bigger elevational range in the Pre-Alps, which resulted in a higher species richness. $\alpha$-Diversity of forest and non-forest were similar, whereas each vegetation formation showed one third of its species restricted to it. The contributions to the total lichen diversity of crustose, foliose and fruticose as well as of generative and vegetative species was calculated. Specific features along the altitudinal gradient of vegetation belts emerged: the percentage of crustose and generative lichens declined with every altitudinal step, increased in fruticose and vegetative lichens, and was the same in foliose species.

1997 The British Lichen Society
\end{abstract}

\section{Introduction}

The conservation of any group of organisms needs basic information on distribution diversity and dynamics. Representative data on the frequency of epiphytic lichens is of key importance when these organisms are used as bioindicators of air pollution or when Red Lists are to be established. In regional studies using epiphytic lichens as indicators of air pollution elaborate sampling designs have been proposed (Herzig \& Urech 1991; Nimis et al. 1991). In conservation biology, however, the data used for creating Red Lists for lichens have so far always been of a qualitative nature (Thor 1995). International and national Red Lists have been published worldwide for many organisms. Based mainly on inventories of the organisms considered, the data used for establishing Red Lists are rarely representative. Unbiased inventories representative of large areas are difficult to carry out for many groups of organisms, either because of seasonality of sessile organisms or the translocation of vagrant organisms.

In Switzerland representative data collection was conducted as part of the Forest Inventory (EAFV 1988). For inconspicuous cryptogams a new method was proposed for the Inventory of the Swiss Bryophyte Flora (Urmi et al.

* Swiss Federal Institute for Forest, Snow and Landscape Research, CH-8903 Birmensdorf, Switzerland 
1990). Switzerland's first Red List of macrolichens is based mainly on the personal field experience of the authors, as well as on herbaria and literature studies (Clerc et al. 1992). In this country, floristic studies on epiphytic lichens were sparse until recently, and mainly took the form of overall investigations of the flora of small, species-rich, forest areas (Camenzind \& Wildi 1991; Dietrich 1991; Groner 1990; Scheidegger et al. 1991). However, the diversity of lichens reported in such studies is usually greatly biased by an unequal consideration of the organisms or the habitats. The first bias is often encountered when species difficult to identify are neglected in a survey, such as sorediate crustose lichens (Dietrich \& Scheidegger 1996a). The second may lead to considerable errors when habitats of organisms with a narrow ecolog: are inaccurately represented.

This study is aimed at contributing to the development of a representative survey of the diversity, distribution and dynamics of epiphytic lichens. Floristic standard sampling (Clerc \& Scheidegger 1990) will in future provide basic information on the epiphytic lichen flora at a regional level, in order to facilitate the compilation of a new Red List including all lichens.

Standardized surveys were conducted in the Swiss Central Plateau and the Pre-Alps. For comparability in time, data collection was carried out on long-term ecological observation plots (EAFV 1988). To be more representative stratified sampling was carried out according to region, vegetation formation (forest and non-forest) and vegetation belt, allowing comparisons of lichen diversity within particular interpretation units ( $u$-diversity) or between them ( $\beta$-diversity). Reliability of the sampling method in terms of species capture was estimated for a particular area known to be rich in lichens. The importance of the crustose, foliose and fruticose growth forms, as well as of the generative and vegetative dispersal types, was also analysed.

\section{Materials and Methods}

\section{Study area and sampling}

In 1993 and 1994 data from 849 trees on 132 long-term ecological observation plots (EAFV' 1988) were sampled. The intersection points of the $1 \times 1 \mathrm{~km}$ grid of the Swiss cuordinate system were taken as plot centres. All the plots are situated in the two regions Central Plateau and Pre-Alps, comprising respectively $22.8 \%$ and $16.0 \%$ of the total surface of Switzerland (Bundesamt für Statistik 1980). Within these regions they are concentrated in the five areas (Fig. 1) established by Welten \& Sutter (1982), ranging from 93 to $131 \mathrm{~km}^{2}$ (Wohlgemuth pers. comm.).

Sampling was performed in terms of region (Central Plateau and Pre-Alps), vegetation formation (forest and non-forest), and vegetation belt (colline-submontane, lower and upper montane, and subalpine). Definitions of the strata follow those of the Swiss Forestry Inventory: (EAFV 1988). In selecting the plots care was taken to ensure that at least ten were chosen for each combination of strata of which there were four in the Central Plateau and eight in the Pre-Alps. Within each combination, plots were selected arbitrarily, taking into account casc of access, but without any special attention to potentially rich habitats.

With an area of $93 \mathrm{~km}^{2}$ extending through all four vegetation belts, Glaubenburg (Fig. 1) in the Pre-Alps (canton of Obwalden) was used as the area with the highest plot density ( 40 plots). To estimate the reliability of the sampling method in terms of species recorded, an overall investigation of the lichen flora of the Merli forest (Dietrich 1991) in Glaubenberg, with a surface of $1 \mathrm{~km}^{2}$ covering the upper montane and the subalpine vegetation belt, as well as additional observations in this area (Dietrich, Frei, Groner \& Scheidegger, unpubl.), were used as the basis for comparison. 


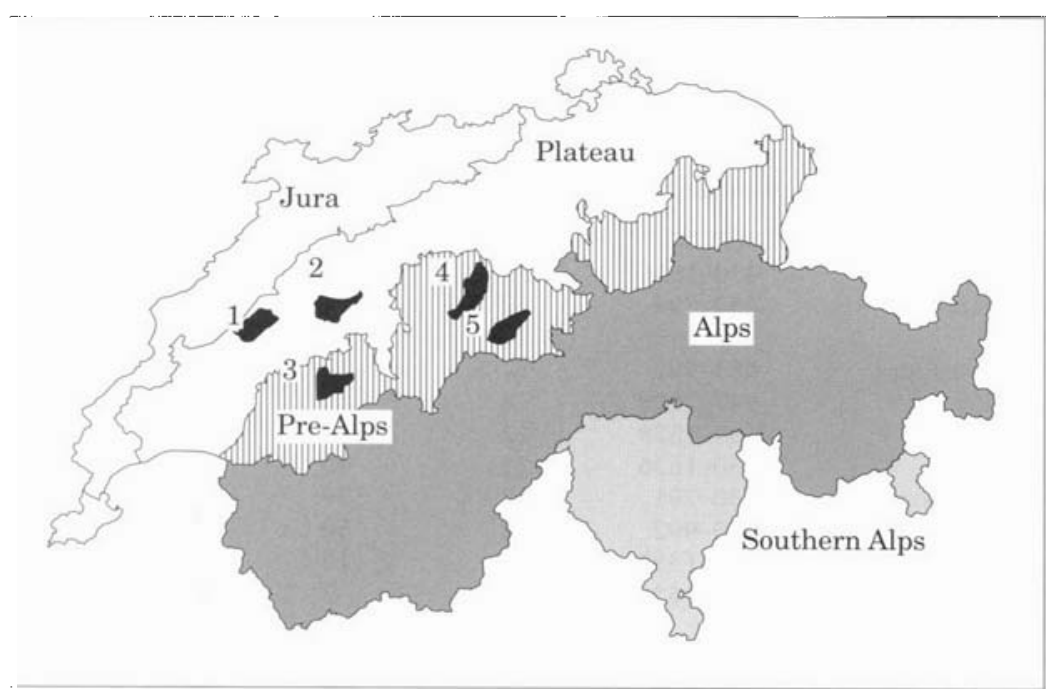

Fig. 1. The Central Plateau and the Pre-Alps of Switzerland with the five plot concentration areas: $1=$ Payerne, $2=$ Bern - West, $3=$ Schwarzsee, $4=$ Entlebuch, $5=$ Glaubenberg.

Ecological plot data for the area of a circle of $500 \mathrm{~m}^{2}(\mathrm{r}=12.62 \mathrm{~m})$ were provided by the Swiss Forest Inventory (EAFV 1982). On each plot every tree with a diameter at breast height $(\mathrm{dbh}) \geq 12 \mathrm{~cm}$ was normally sampled, although with a maximum of three individuals per phorophyte species and dbh-class of $12 \mathrm{~cm}$.

The entire epiphytic lichen flora including the different species of Lepraria (Tonsberg 1992), was recorded for all trees (stem height of $0-170 \mathrm{~cm}$ ) as cover percentage of the stem investigated (Dietrich \& Scheidegger 1996b). The lichen flora of twigs and branches was not included. In addition to lichen data, phorophyte species, the dbh of every tree and the percentage of the overall cover of bryophytes was estimated. The two varieties of Opegrapha vulgata s. lat. and Parmelia quercina s. lat. as well as the two forms of Lecanora allophana s. lat. were treated in all calculations as distinct species. Affiliation of species to crustose, foliose and fruticose growth forms as well as to generative and vegetative dispersal types was determined according to Wirth (1992).

\section{Data analysis}

Data were analysed for 19 different interpretation units (Table 1): study area, eight strata, eight combinations of strata in the Pre-Alps, Lower Pre-Alps (colline-submontane and lower montane belt) and upper Pre-Alps (upper montane and subalpine).

The frequency distributions of lichen species were based on presence/absence data per tree and per plot. The determination of their pattern was based on classification on a linear scale as well as on species rank-abundance plots. Mathematical fit was tested according to Magurran (1988). The establishment of four classes of scarcity of lichens, each accounting for $25 \%$ of the total number of the species, was based on abundance of plots in which they occurred. The most frequent species were determined for the strata as well as for their 12 combinations.

$u$-Diversity was calculated for all interpretation units in terms of species richness, which is the number of species. The Shannon index, another index of $a$-diversity, was calculated using the formula $H^{\prime}=-2\left(p_{i}{ }^{\star} \ln p_{j}\right)$, where $p_{i}$ is the percentage of plots with the lichen species $i$. The mean species number per plot and interpretation unit was calculated to give the species density. Species restricted to one interpretation unit are based on the occurrence in the corresponding level of stratification. $\beta$-Diversity between two interpretation units was calculated in terms of dissimilarity using the formula $\mathrm{d}=1-2 n_{\mathrm{a}+\mathrm{b}^{\prime}}\left(n_{\mathrm{a}}+n_{\mathrm{b}}\right)$, with $\mathrm{d}=$ dissimilarity, $n_{\mathrm{a}}=$ species number in one unit, $n_{\mathrm{b}}=$ species number in the other unit and $n_{\mathrm{a}+\mathrm{b}}=$ species that both units have in common. $\beta$-Diversity between more than two interpretation units was determined for every unit as the average of the dissimilarities from each of the other units involved. 
TABLE 1. Altitude and phorophyte composition represented by the plots of the 19 different interpretution units

\begin{tabular}{|c|c|c|c|c|c|}
\hline Interpretation unit & Altitude (m) & $\begin{array}{c}\text { Number of } \\
\text { phorophyte } \\
\text { species }\end{array}$ & $\begin{array}{c}\text { Deciduous } \\
\text { trec trunks } \\
(1 / 1)\end{array}$ & $\begin{array}{c}\text { Coniferous } \\
\text { treo trunks } \\
(1 / 1 /)\end{array}$ & $\begin{array}{l}\text { Sumber } \\
\text { of plots }\end{array}$ \\
\hline Study area & $430-1636$ & 31 & 47 & 53 & 132 \\
\hline Central Plateau & $430-799$ & 22 & 70 & 30 & 44 \\
\hline Pre-Alps & $483-1636$ & 28 & 37 & 63 & 88 \\
\hline Lower Pre-Alps & $483-992$ & 27 & 63 & 37 & 44 \\
\hline Upper Pre-Alps & $947-1636$ & 8 & 11 & 89 & 44 \\
\hline Non-forest & $483-1578$ & 22 & 64 & 36 & 63 \\
\hline Forest & $430-1636$ & 21 & 40 & 60 & 69 \\
\hline Colline-submontane & $430-791$ & 27 & 79 & 21 & 44 \\
\hline Lower montane & $620-992$ & 22 & 50 & 50 & 44 \\
\hline Upper montane & $947-1357$ & 6 & 19 & 81 & 24 \\
\hline Subalpine & $1322-1636$ & 5 & 2 & 98 & 20 \\
\hline \multicolumn{6}{|l|}{ Pre-Alps, non-forest } \\
\hline Colline-submontane & $483-779$ & 16 & 96 & 4 & 10 \\
\hline Lower montane & $641-992$ & 14 & 89 & 11 & 10 \\
\hline Upper montane & $1010-1333$ & 4 & 31 & 69 & 10 \\
\hline Subalpine & $1328-1553$ & 1 & 0 & 100 & 14 \\
\hline \multicolumn{6}{|l|}{ Pre-Alps, forest } \\
\hline Colline-submontane & $495-791$ & 11 & 64 & 36 & 10 \\
\hline Lower montane & $620-983$ & 11 & 37 & 63 & 10 \\
\hline Upper montane & $947-1357$ & 5 & 13 & 87 & 14 \\
\hline Subalpine & $1322-1636$ & 5 & 3 & 97 & 10 \\
\hline
\end{tabular}

For all interpretation units the mean percentage \pm standard deviation of crustose, foliose and fruticose, as well as of generative and vegetative lichens was calculated per plot, by setting the flora of each plot at $100 \%$, regardless of the number of species.

\section{Results}

\section{Ecological plot data}

Along the altitudinal gradient of vegetation belts, the ranges of altitude overlap up to $171 \mathrm{~m}$ (Table 1). As a result of higher tree density the number of trees examined was larger in forest (570) than in non-forest (279) areas. Numbers of different phorophyte species decrease distinctly along the altitudinal gradient of vegetation belts (Table 1). Of the 849 trees investigated $47 \%$ were deciduous and 53\% coniferous. Picea abies dominates in each interpretation unit, from $25 \%$ (Central Plateau) to $100 \%$ of the tree trunks (Pre-Alps, subalpine, non-forest), except in the overall colline-submontane belt (Fagus sylvatica with 22\%), the non-forest (Malus, 27\%) and forest plots (Fagus sylvatica, 44\%) of the colline-submontane belt in the Pre-Alps, and the non-forest plots of the lower montane belt in the Pre-Alps (Salix alba, 19\%).

\section{Frequency}

The distributions of frequencies of lichens, calculated for plots and trees, have similar patterns. The $10 \%$ frequency classes based on the 849 trees show 


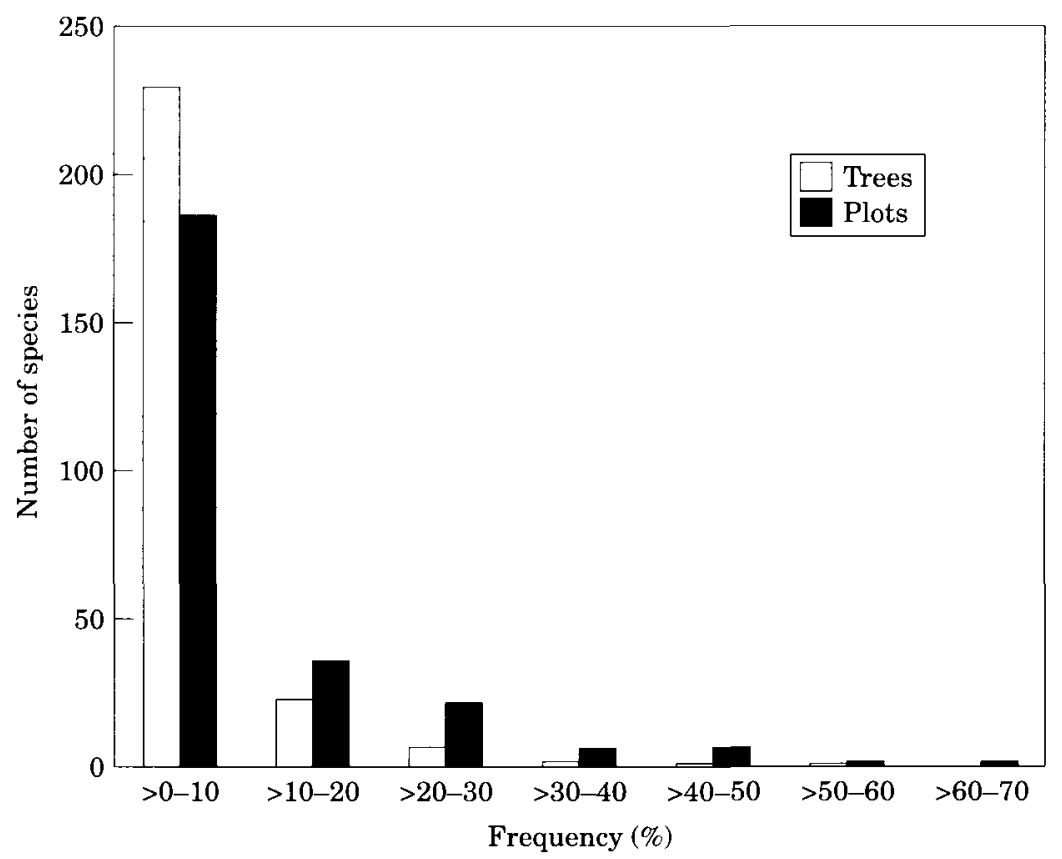

Fig. 2. Distribution of classified frequency of the 262 lichen species.

229 species $(87 \%)$ in the lowest class (Fig. 2); $47(18 \%)$ were found on one tree only. Based on the plots, 59 species $(23 \%)$ were found on one plot. Only 18 species $(6.9 \%)$ occurred on more than $30 \%$ of the plots (Fig. 2 ). Derived species rank-abundance plots based on trees and plots (Fig. 3) are both approximately linear, corresponding to the log series of species abundance models (Magurran 1988). However, testing of mathematical fit, only reveals a high value $(P>0.90)$ for the frequencies based on trees, but not for the plots $(P=0 \cdot 10)$. Mathematical fit with the truncated $\log$ normal distribution of species abundance is $P<0.10$ for the trees, and $P<0.01$ for the plots.

As data from different trees of one plot are not independent, at regional level the frequency based on the plot level is more representative than that based on the tree level. Total study area, Central Plateau and Pre-Alps show similar distribution of species abundance (Fig. 4). They differ only with regard to the highest score (this probably originated from the different total number of plots investigated). The presence of the common frequency distribution enables us to create the same classes of scarcity for epiphytic lichen species. Each of the four classes (very rare, rare, moderately common and common) represents $25 \%$ of the total species number. To determine their boundaries, the relative sums of species occurring in the three regional interpretation units per relative number of plots were averaged. The boundaries correspond to the values of 25,50 and $75 \%$ of species sum. Mathematically they are given by 1,4 and $15 \%$ of the total number of plots investigated. Because the number of the plots 


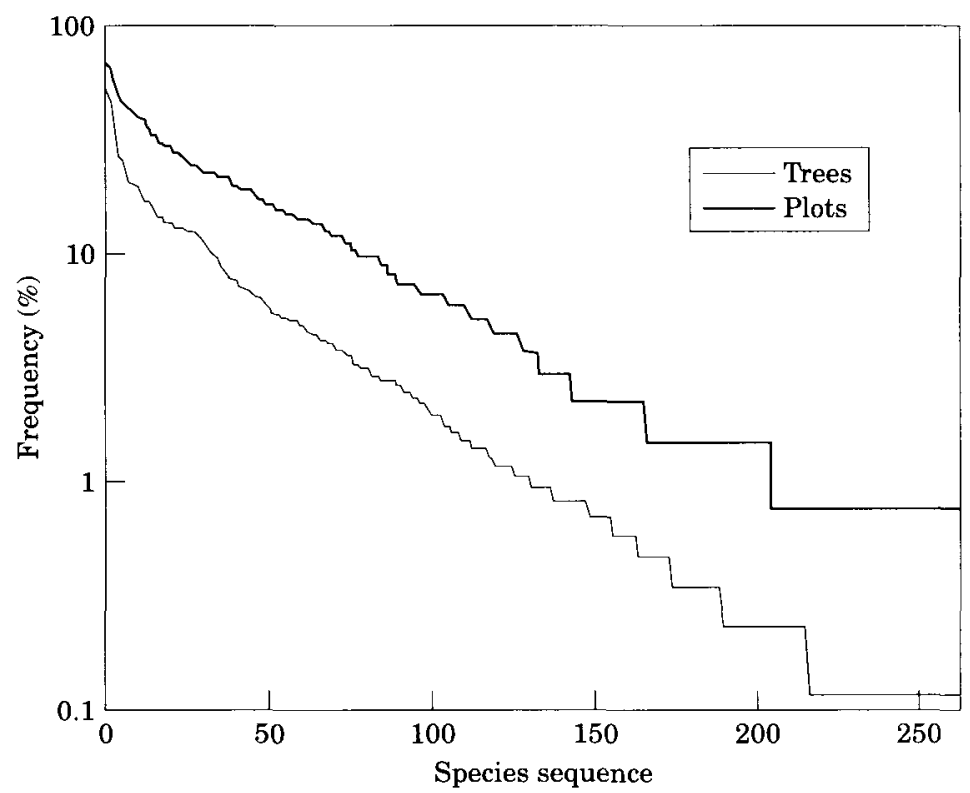

FIG. 3. Rank abundance plots showing the distribution of frequency of the 262 lichen species, based on 849 trees and 132 plots.

in Central Plateau and the Pre-Alps is below 100, correct processing of these classes is only possible for the entire study area (Table 2).

When considering each stratum individually, the number of species that occurred with the three highest scores in at least one of the strata is only ten (Table 3). For the ten most abundant species within the study area, only Lepraria rigidula, Parmelia glabratula and Candelariella reflexa must be added. A further abundant species, Xanthoria parietina, is restricted to non-forest in the lower vegetation belts (colline-submontane $100 \%, 90 \%$ of the plots in Central Plateau and Pre-Alps, respectively; lower montane in Central Plateau and Pre-Alps each 90\%). Cladonia digitata, Platismatia glauca and Hypogymnia farinacea each have values of $100 \%$ in forest of the subalpine belt (Pre-Alps). In addition, the latter appears on $80 \%$ of the forest plots in the upper montane belt (Pre-Alps). In the forest plots of the colline-submontane and lower montane belt of the Pre-Alps, Graphis scripta has values of 90 and $86 \%$, respectively. Finally Arthonia radiata, with $73 \%$, has one of the highest scores in forest plots in the colline-submontane vegetation belt of the Central Plateau.

\section{Diversity}

Within the study area, species richness as an expression of $\alpha$-diversity amounts to 262 , including two species with two varieties and one species with two forms (Table 2). Nine taxa were not determined to species level. Their supposed systematic relationship is indicated where possible. Of the 182 crustose, 55 foliose and 25 fruticose taxa, the records of several sorediate 


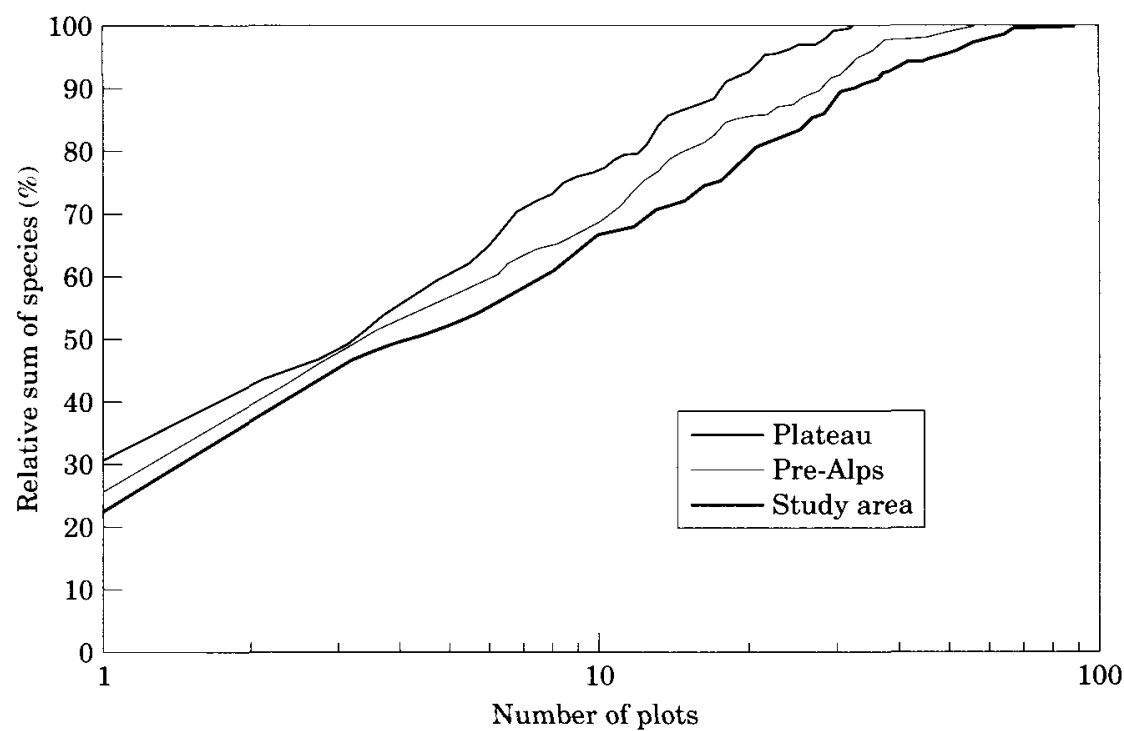

FIG. 4. Cumulative frequency within the regional interpretation units Central Plateau, Pre-Alps and in the entire study area.

crustose species are of particular floristic importance: 13 were reported as new to Switzerland, and seven taxa with distinctive chemistry could not be determined yet (Dietrich \& Scheidegger 1996a). Furthermore, the sampling method revealed several taxa from the Red List of macrolichens of Switzerland (Clerc et al. 1992), whereas Anaptychia ciliaris, Leptogium saturninum, Menegazzia terebrata and Parmelia acetabulum were found on more than one plot. Cladonia incrassata, indicated as a species in danger of extinction, was found for the second time in Switzerland.

The 132 plots, with an average of six trees studied, showed a mean number of 24 species, corresponding to $9 \%$ of the total flora investigated. At least one species was observed on every plot, whereas the maximum number was 49 per plot and 35 per tree trunk. Comparing Central Plateau and Pre-Alps (Table 4 ), $\alpha$-diversity expressed by the species richness $(134,243$, respectively) was higher in the latter, with $53 \%$ of the taxa restricted to this region. In addition, species density measured by the number per plot was significantly higher ( $t$-test, $P<0 \cdot 001)$, but the percentage of the corresponding total flora was higher in the Central Plateau (15\%). Distinguishing lower from upper Pre-Alps in addition to the Central Plateau (Table 4), 48\% of the taxa of the upper Pre-Alps were still restricted to this interpretation unit. Compared to the Central Plateau, species density is significantly higher only in the upper Pre-Alps $(P<0.001)$.

Compared to the regional strata, the calculated differences in diversity between the strata of vegetation formation are very low (Table 4). Both, forest and non-forest revealed similar species densities, although the average number of trees investigated was four in non-forest and eight in forest. 


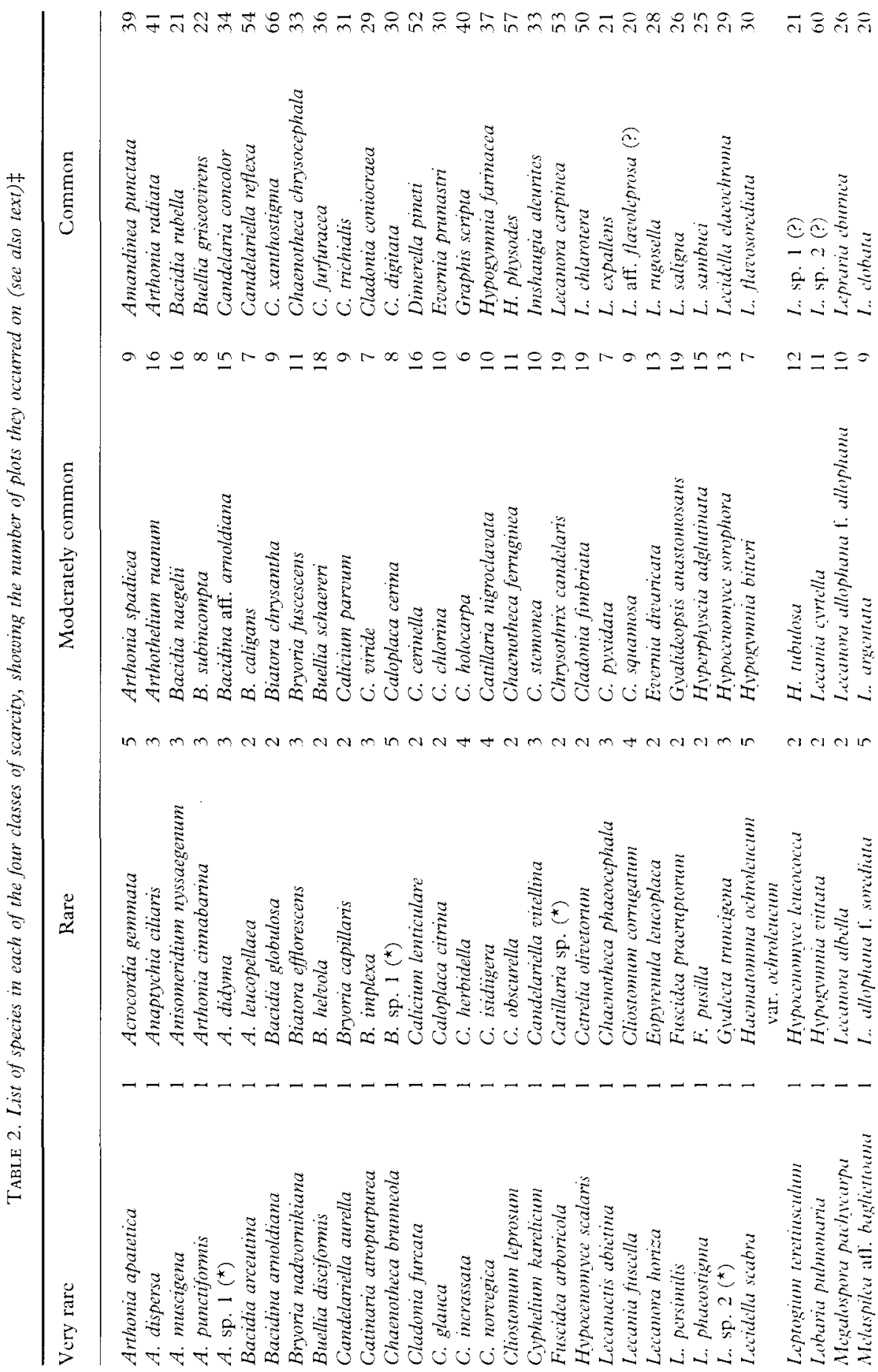




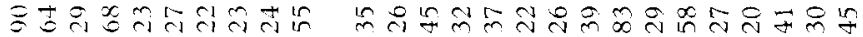
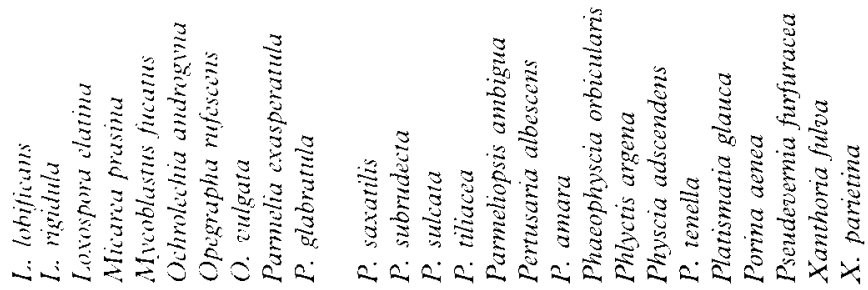

$\operatorname{grobm} 20 \Omega \propto$

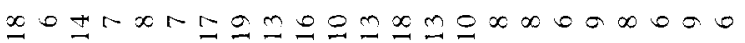
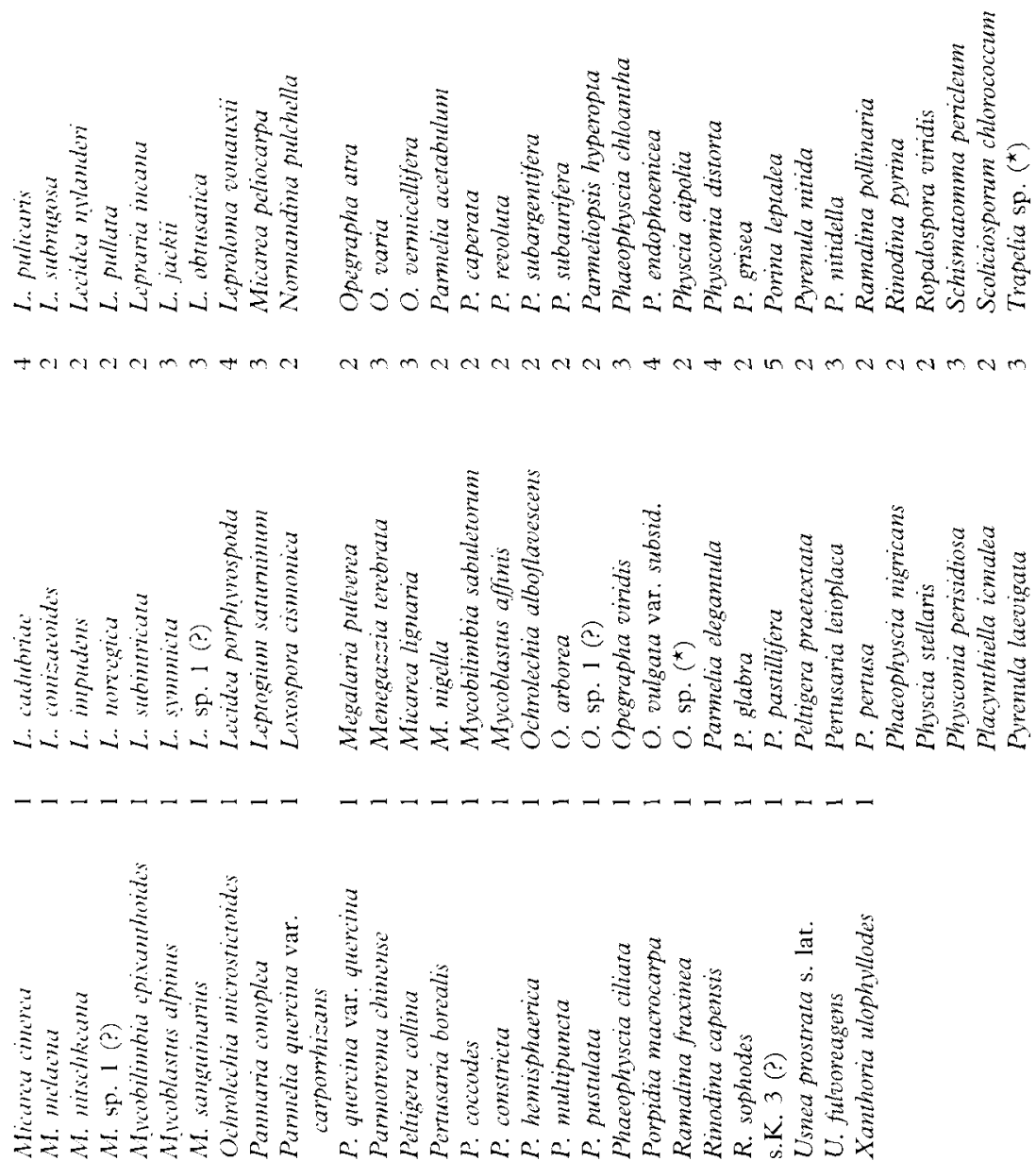


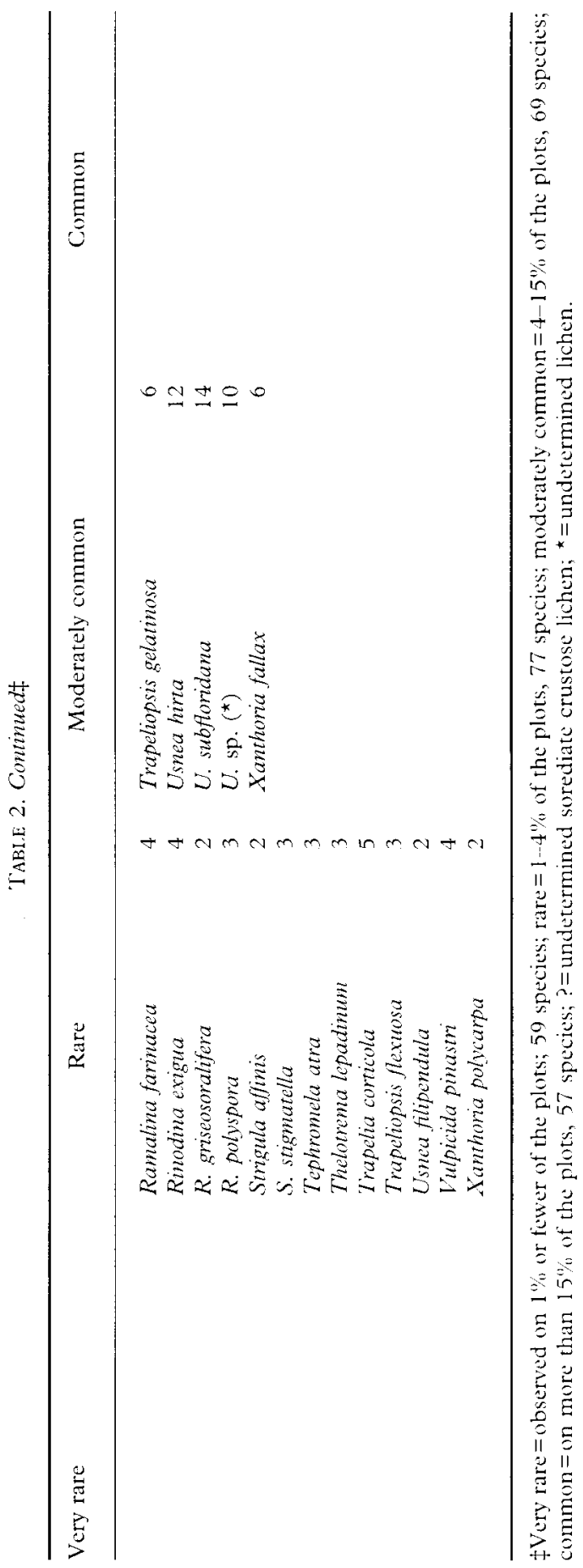




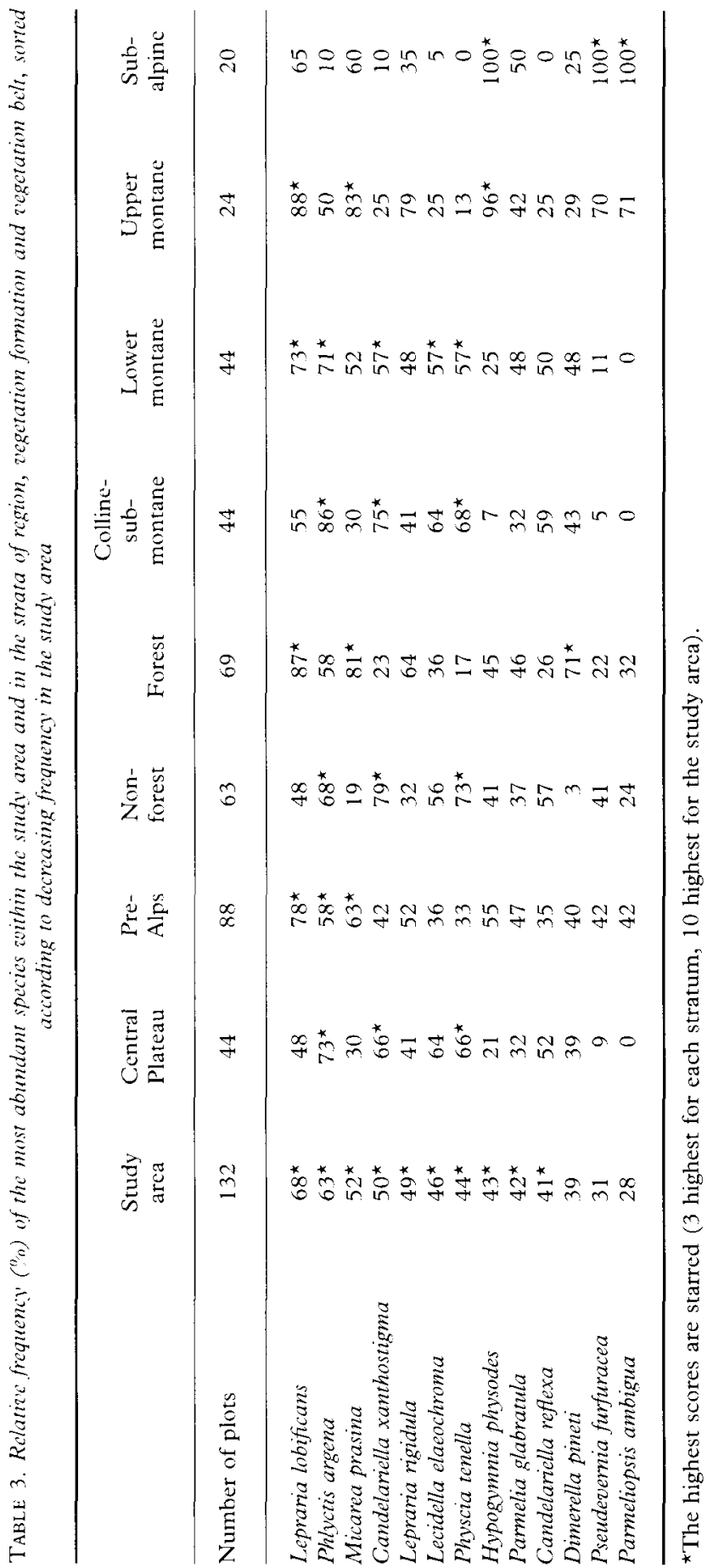


TABLE 4. Diversity within the strata of region, vegetation formation and vegetation belt, and within lower and upper Pre-Alps

\begin{tabular}{|c|c|c|c|c|c|}
\hline Interpretation unit & $\begin{array}{l}\text { Species } \\
\text { richness }\end{array}$ & $\begin{array}{l}\text { Restricted to } \\
\text { interpretation } \\
\text { unit }(\%)\end{array}$ & $\begin{array}{l}\text { Mean species } \\
\text { number per plot } \\
\text { (species density) }\end{array}$ & $\begin{array}{l}\text { Mean percentage } \\
\text { per plot of flora } \\
\text { of interpretation } \\
\text { unit } \\
(1 / 1)\end{array}$ & $\begin{array}{l}\text { Number } \\
\text { of plots }\end{array}$ \\
\hline Central Plateau & 134 & 14 & $20 \pm 10$ & $15 \pm 7$ & 44 \\
\hline Pre-Alps & 243 & 53 & $26 \pm 10$ & $11 \pm 4$ & 88 \\
\hline Lower Pre-Alps & 147 & 13 & $22 \pm 7$ & $18 \pm 5$ & 44 \\
\hline Upper Pre-Alps & 184 & 48 & $30 \pm 11$ & $16 \pm 6$ & 44 \\
\hline Non-forest & 195 & 31 & $25 \pm 9$ & $13 \pm 4$ & 63 \\
\hline Forest & 202 & 33 & $23 \pm 11$ & $11 \pm 6$ & 69 \\
\hline Colline-submontane & 141 & 17 & $22 \pm 8$ & $16 \pm 6$ & 44 \\
\hline Lower montane & 145 & 9 & $20 \pm 9$ & $14 \pm 6$ & 44 \\
\hline Upper montane & 160 & 20 & $30 \pm 12$ & $18 \pm 7$ & 24 \\
\hline Subalpine & 114 & 16 & $30 \pm 9$ & $26 \pm 8$ & 20 \\
\hline
\end{tabular}

TABLE 5. Diversity along the altitudinal gradient of vegetation belts in the Pre-Alps region, non-forest and forest stratum separately

\begin{tabular}{|c|c|c|c|c|}
\hline Interpretation unit & $\begin{array}{l}\text { Species } \\
\text { richness }\end{array}$ & $\begin{array}{l}\text { Mean species } \\
\text { number per plot } \\
\text { (species density) }\end{array}$ & $\begin{array}{c}\text { Mean percentage } \\
\text { per plot of flora } \\
\text { of interpretation } \\
\text { unit } \\
(\%)\end{array}$ & $\begin{array}{l}\text { Number } \\
\text { of plots }\end{array}$ \\
\hline \multicolumn{5}{|l|}{ Non-forest } \\
\hline Colline-submontane & 78 & $25 \pm 8$ & $32 \pm 10$ & 10 \\
\hline Lower montane & 78 & $25 \pm 6$ & $31 \pm 8$ & 10 \\
\hline Upper montane & 110 & $26 \pm 13$ & $24 \pm 11$ & 10 \\
\hline Subalpine & 77 & $26 \pm 8$ & $34 \pm 11$ & 10 \\
\hline \multicolumn{5}{|l|}{ Forest } \\
\hline Colline-submontane & 73 & $21 \pm 8$ & $29 \pm 11$ & 10 \\
\hline Lower montane & 85 & $18 \pm 6$ & $22 \pm 7$ & 14 \\
\hline Upper montane & 119 & $32 \pm 11$ & $27 \pm 9$ & 14 \\
\hline Subalpine & 91 & $34 \pm 9$ & $38 \pm 9$ & 10 \\
\hline
\end{tabular}

Along the altitudinal gradient (Table 4) species richness is highest in the upper montane (160) and lowest in the subalpine belt (114). In the latter the low total species number and the highest density result in a mean percentage of $26 \%$ per plot of its total flora. If forests and non-forest areas are distinguished in the Pre-Alps (Table 5), patterns of diversity along the vegetation belts do not change distinctly. In both areas species richness was clearly highest in the upper montane belt. The non-forest plots were responsible for the low species richness in the subalpine belt. Of all interpretation units, forest of the subalpine belt showed the highest species density (34). 


\begin{tabular}{lccc} 
Table 6. Dissimilarity between & $\begin{array}{c}\text { Central Plateau, lower Pre-Alps and upper } \\
\text { Pre-Alps }\end{array}$ \\
\hline Region & Lower Pre-Alps & Upper Pre-Alps & Average \\
\hline Central Plateau & 0.23 & 0.53 & 0.38 \\
Lower Pre-Alps & 0 & 0.47 & 0.35 \\
Lpper Pre-Alps & & 0 & 0.5 \\
\hline
\end{tabular}

According to Magurran (1988) the Shannon indices of lichen diversity in all interpretation units are too high, reaching up to 4.91 for the entire study area. This is a result of the relatively low sampling size for heterogeneous units, in which no attention was paid to homogeneity in habitat or community. Nevertheless, ranking of Shannon indices always reflects the same order of the different interpretation units as the ranking of species richness.

For the estimation of species capture 40 plots were located in the Glaubenberg area, well known for the rich epiphytic lichen flora. The 40 plots revealed 205 lichen species. By adding observations from the lichen-rich Merli forest (Dietrich 1991) and other species from Glaubenberg (Dietrich, Frei, Groner \& Scheidegger, unpublished) not observed in this study, the number of epiphytic species amounts to 296 . Treating the 296 species found in Glaubenberg as its total epiphytic lichen flora, $69 \%$ of these were detected in the 40 plots investigated. By looking only at forest in the upper montane and subalpine belt of Glaubenberg, the flora of the corresponding 19 plots shows 134 species. With the additional Merli forest observations (Dietrich 1991), including species found only on branches and above a stem height of $1.70 \mathrm{~m}$, richness increases to 231 . Together, the 19 sites revealed $58 \%$ of this flora. In the Merli forest only one plot, with 43 different species, or $23 \%$ of the total forest lichen flora, was investigated in this study. The reliability of the sampling method, expressed by the species capture per plot for a given area, each with a well-known lichen flora, is evidently high: for the Glaubenberg area $\left(93 \mathrm{~km}^{2}\right)$ one plot $\left(500 \mathrm{~m}^{2}\right)$ revealed on average $11 \%$ of the flora, whereas forest in the upper montane and subalpine vegetation belt in the same area $\left(24 \mathrm{~km}^{2}\right)$ yielded an average of $16 \%$, and Merli forest $\left(1 \mathrm{~km}^{2}\right) 23 \%$.

As a measurement of $\beta$-diversity the calculated dissimilarity between the Central Plateau and Pre-Alps amounts of 0.38. Distinguishing again lower from upper Pre-Alps in addition to the Central Plateau (Table 6), the upper Pre-Alps on average shows the highest value of dissimilarity, as already reflected by the highest percentage of species restricted to this interpretation unit. Altitudinal division within one strata of region results in a much higher value of dissimilarity than regional division of the same altitudes.

Although the $\alpha$-diversity of forest and non-forest plots was not significantly different, the calculated value of dissimilarity amounts to 0.32 . This reflects the different species composition of the two strata, which have two thirds of the species in common.

Along the altitudinal gradient, dissimilarity in terms of $\beta$-diversity between the colline-submontane and each of the higher vegetation belts increases 
TABLE 7. Dissimilarity between the four vegetation belts and between the four vegetation belts in the Pre-Alps region, non-forest and forest stratum separately

\begin{tabular}{lllll}
\hline Interpretation unit & $\begin{array}{c}\text { Lower } \\
\text { montane }\end{array}$ & $\begin{array}{c}\text { Upper } \\
\text { montane }\end{array}$ & Subalpine & Average \\
\hline Colline-submontane & 0.21 & 0.5 & 0.65 & 0.45 \\
Lower montane & 0 & 0.42 & 0.58 & 0.4 \\
Upper montane & & 0 & 0.34 & 0.42 \\
Subalpine & & & 0 & 0.52 \\
Non-forest & 0.32 & 0.65 & 0.82 & 0.6 \\
$\quad$ Colline-submontane & 0 & 0.49 & 0.7 & 0.5 \\
$\quad$ Lower montane & & 0 & 0.37 & 0.5 \\
$\quad$ Upper montane & & & 0 & 0.63 \\
$\quad$ Subalpine & 0.33 & 0.55 & 0.62 & 0.5 \\
Forest & 0 & 0.51 & 0.59 & 0.48 \\
$\quad$ Colline-submontane & & 0 & 0.33 & 0.46 \\
Lower montane & & & 0 & 0.51 \\
$\quad$ Upper montane & & & & \\
Subalpine & & & & \\
\hline
\end{tabular}

continuously with altitude (Table 7). Dissimilarity from the subalpine to the lower belts increases with altitudinal distance as well. On average the subalpine belt has the highest $\beta$-diversity. As the lower montane belt shows a smaller dissimilarity to the colline-submontane $(0.21)$ than to the upper montane $(0.42)$, and the latter a smaller one to the subalpine $(0.34)$ than to the lower montane $(0 \cdot 42)$, altitudinal division between the lower and upper montane belt reveals the greater differences in the flora of epiphytic lichens.

When forest areas are distinguished from non-forest areas in the Pre-Alps (Table 7), increasing floristic differences with altitudinal distance is more evident in non-forest. Here dissimilarity between the colline-submontane and the subalpine vegetation belt reaches the very high value of 0.82 . Dissimilarity between non-forest and forest in each of the four vegetation belts decreases markedly with altitude, from 0.55 in the colline-submontane to 0.42 in the lower montane, 0.40 in the upper montane and 0.36 in the subalpine belt.

\section{Ecological strategies}

With a percentage of $70 \%$, corresponding to 182 species, crustose lichens are by far the most abundant growth form (Table 8). For the study area, calculations of the mean contribution of each growth form to the flora per plot results in statistically significant ranking: Crustose $>$ foliose ( $t$-test, $P=<0.001)>$ fruticose $(P=<0.001)$.

Although generative and vegetative types of dispersal are almost equally distributed among the lichen species observed (Table 8), their mean percentages of the flora per plot differs significantly $(P<0 \cdot 001): 35 \%$ are constituted by generative lichen species. Only for crustose lichens is the number of generative species higher. Nevertheless, for vegetative dispersal the mean percentage of the flora per plot is significantly higher for foliose $(P=<0.001)$ and fruticose lichens $(P=<0 \cdot 001)$. 
TABLE 8. Thalu's of importance for growth forms and dispersal types in the study area

\begin{tabular}{lcc}
\hline & $\begin{array}{c}\text { Number of } \\
\text { species }(\%)\end{array}$ & $\begin{array}{c}\text { Mean percentage } \\
\text { per plot } \\
(\%)\end{array}$ \\
\hline Parameters & & $67 \pm 19$ \\
$\quad$ Crustose & 70 & $26 \pm 17$ \\
Foliose & 21 & $7 \pm 8$ \\
Fruticose & 9 & $65 \pm 17$ \\
Dispersal type & & $35 \pm 17$ \\
Vegetative & 54 & $36 \pm 14$ \\
Gencrative & 46 & $32 \pm 18$ \\
Growth and dispersal & & $23 \pm 14$ \\
Crustose, vegetative & 29 & $3 \pm 5$ \\
Crustose, generative & 41 & $6 \pm 8$ \\
Foliose, vegetative & 17 & $0.24 \pm 0 \cdot 84$ \\
Foliose, generative & 4 & \\
Fruticose, vegetative & 8 & \\
Fruticose, gencrative & 1 & \\
\hline
\end{tabular}

All the following results are based on the mean percentages per plot. Absolute species numbers show only slight similarities, if at all. For the Central Plateau, Pre-Alps, forest, non-forest as well as for the collinesubmontane, lower and upper montane and subalpine vegetation belts, the analysed mean percentages of growth forms and dispersal types show the same ranking of importance as for the entire study area: crustose $>$ foliose $(P=<0.001)>$ fruticose growth form $(P \leqslant 0.005)$, and vegetative $>$ generative dispersal type $(P<0.001)$.

Comparing the Central Plateau with the Pre-Alps, significant differences within the growth forms were observed for the fruticose species only ( $2 \%$ and $9 \%$, respectively; $P=0.003$ ). In addition, the calculated values for vegetative $(55 \%, 70 \%)$ and for generative dispersal $(45 \%, 30 \% ; P<0.005)$ differ significantly.

For forest and non-forest, calculated values for dispersal types and fruticose species are similar to those of the entire study area. Differences between the two vegetation formations are obvious for crustose and foliose lichens. The former have a significantly higher mean percentage per plot in forest $(79 \%)$ than in non-forest $(55 \% ; P=<0.001)$, while the latter show a significantly higher mean percentage in non-forest (39\%) compared to forest $(15 \%$; $P=<0 \cdot 001$ ).

Looking at the altitudinal gradient (Fig. 5), only for foliose lichens are the mean percentages per plot more or less the same in every vegetation belt. The importance of the crustose growth form decreases from colline-submontane to the higher belts (not significant). In contrast, the importance of the fruticose form increases from low to higher altitudes (not significant). A similar pattern is obvious for the two types of dispersal: values for vegetative lichens increase significantly with every altitudinal step, and as a consequence those of generative lichens decline in the same manner from the colline-submontane to 
TABLE 7. Dissimilarity betzeen the four vegetation belts and between the fou vegetation belts in the Pre-Alps region, non-forest and forest stratum separately

\begin{tabular}{|c|c|c|c|c|}
\hline Interpretation unit & $\begin{array}{l}\text { Lower } \\
\text { montane }\end{array}$ & $\begin{array}{l}\text { Upper } \\
\text { montane }\end{array}$ & Subalpine & Average \\
\hline Colline-submontane & $0 \cdot 21$ & $0 \cdot 5$ & 0.65 & $0 \cdot 45$ \\
\hline Lower montane & 0 & $0 \cdot 42$ & 0.58 & $0 \cdot 4$ \\
\hline Upper montane & & 0 & 0.34 & $0 \cdot+2$ \\
\hline Subalpine & & & 0 & 0.52 \\
\hline \multicolumn{5}{|l|}{ Non-forest } \\
\hline Colline-submontane & $0 \cdot 32$ & 0.65 & 0.82 & 0.6 \\
\hline Lower montane & 0 & $0 \cdot 49$ & 0.7 & 0.5 \\
\hline Upper montane & & 0 & 0.37 & $0 \cdot \overline{5}$ \\
\hline Subalpine & & & 0 & 0.63 \\
\hline \multicolumn{5}{|l|}{ Forest } \\
\hline Colline-submontane & 0.33 & 0.55 & $0 \cdot 62$ & $0 \cdot \overline{5}$ \\
\hline Lower montane & 0 & 0.51 & 0.59 & $0 \cdot 48$ \\
\hline Upper montane & & 0 & 0.33 & 0.46 \\
\hline Subalpine & & & 0 & 0.51 \\
\hline
\end{tabular}

continuously with altitude (Table 7 ). Dissimilarity from the subalpine to the lower belts increases with altitudinal distance as well. On average the subalpine belt has the highest $\beta$-diversity. As the lower montane belt shows a smaller dissimilarity to the colline-submontane $(0.21)$ than to the upper montane $(0.42)$, and the latter a smaller one to the subalpine $(0 \cdot 34)$ than to the lower montane $(0.42)$, altitudinal division between the lower and upper montane belt reveals the greater differences in the flora of epiphytic lichens.

When forest areas are distinguished from non-forest areas in the Pre-Alps (Table 7), increasing floristic differences with altitudinal distance is more evident in non-forest. Here dissimilarity between the colline-submontane and the subalpine vegetation belt reaches the very high value of $0 \cdot 82$. Dissimilarity between non-forest and forest in each of the four vegetation belts decreases markedly with altitude, from 0.55 in the colline-submontane to 0.42 in the lower montane, 0.40 in the upper montane and 0.36 in the subalpine belt.

\section{Ecological strategies}

With a percentage of $70 \%$, corresponding to 182 species, crustose lichens are by far the most abundant growth form (Table 8). For the study area, calculations of the mean contribution of each growth form to the flora per plot results in statistically significant ranking: Crustose $>$ foliose ( $t$-test, $P=<0.001)>$ fruticose $(P=<0.001)$.

Although generative and vegetative types of dispersal are almost equally distributed among the lichen species observed (Table 8 ), their mean percentages of the flora per plot differs significantly $(P<0.001): 35 \%$ are constituted by generative lichen species. Only for crustose lichens is the number of generative species higher. Nevertheless, for vegetative dispersal the mean percentage of the flora per plot is significantly higher for foliose $(P=<0 \cdot 001)$ and fruticose lichens $(P=<0 \cdot 001)$. 
TABLE 8. I Thlues of importunce for growth forms and dispersal types in the study area

\begin{tabular}{lcc}
\hline & $\begin{array}{c}\text { Number of } \\
\text { species }(\%)\end{array}$ & $\begin{array}{c}\text { Mean percentage } \\
\text { per plot } \\
(\%)\end{array}$ \\
Parameters & & \\
\hline Growth form & 70 & $67 \pm 19$ \\
$\quad$ Crustose & 21 & $26 \pm 17$ \\
Foliose & 9 & $7 \pm 8$ \\
Fruticose & & $65 \pm 17$ \\
Dispersal type & 54 & $35 \pm 17$ \\
Vegetative & 46 & $36 \pm 14$ \\
Generative & & $32 \pm 18$ \\
Growth and dispersal & 29 & $23 \pm 14$ \\
Crustose, vegetative & 41 & $3 \pm 5$ \\
Crustose, gencrative & 17 & $6 \pm 8$ \\
Foliose, vegetative & 4 & $0 \cdot 24 \pm 0 \cdot 84$ \\
Foliose, generative & 8 & \\
Fruticose, vegetative & 1 & \\
Fruticose, gencrative & & \\
\hline
\end{tabular}

All the following results are based on the mean percentages per plot. Absolute species numbers show only slight similarities, if at all. For the Central Plateau, Pre-Alps, forest, non-forest as well as for the collinesubmontane, lower and upper montane and subalpine vegetation belts, the analysed mean percentages of growth forms and dispersal types show the same ranking of importance as for the entire study area: crustose $>$ foliose $(P=<0.001)>$ fruticose growth form $(P \leqslant 0.005)$, and vegetative $>$ generative dispersal type $(P<0.001)$.

Comparing the Central Plateau with the Pre-Alps, significant differences within the growth forms were observed for the fruticose species only $(2 \%$ and $9 \%$, respectively; $P=0.003)$. In addition, the calculated values for vegetative $(55 \%, 70 \%)$ and for generative dispersal $(45 \%, 30 \% ; P<0.005)$ differ significantly.

For forest and non-forest, calculated values for dispersal types and fruticose species are similar to those of the entire study area. Differences between the two vegetation formations are obvious for crustose and foliose lichens. The former have a significantly higher mean percentage per plot in forest $(79 \%)$ than in non-forest $(55 \% ; P=<0.001)$, while the latter show a significantly higher mean percentage in non-forest $(39 \%)$ compared to forest $(15 \%$; $P=<0 \cdot 001$ ).

Looking at the altitudinal gradient (Fig. 5), only for foliose lichens are the mean percentages per plot more or less the same in every vegetation belt. The importance of the crustose growth form decreases from colline-submontane to the higher belts (not significant). In contrast, the importance of the fruticose form increases from low to higher altitudes (not significant). A similar pattern is obvious for the two types of dispersal: values for vegetative lichens increase significantly with every altitudinal step, and as a consequence those of generative lichens decline in the same manner from the colline-submontane to 


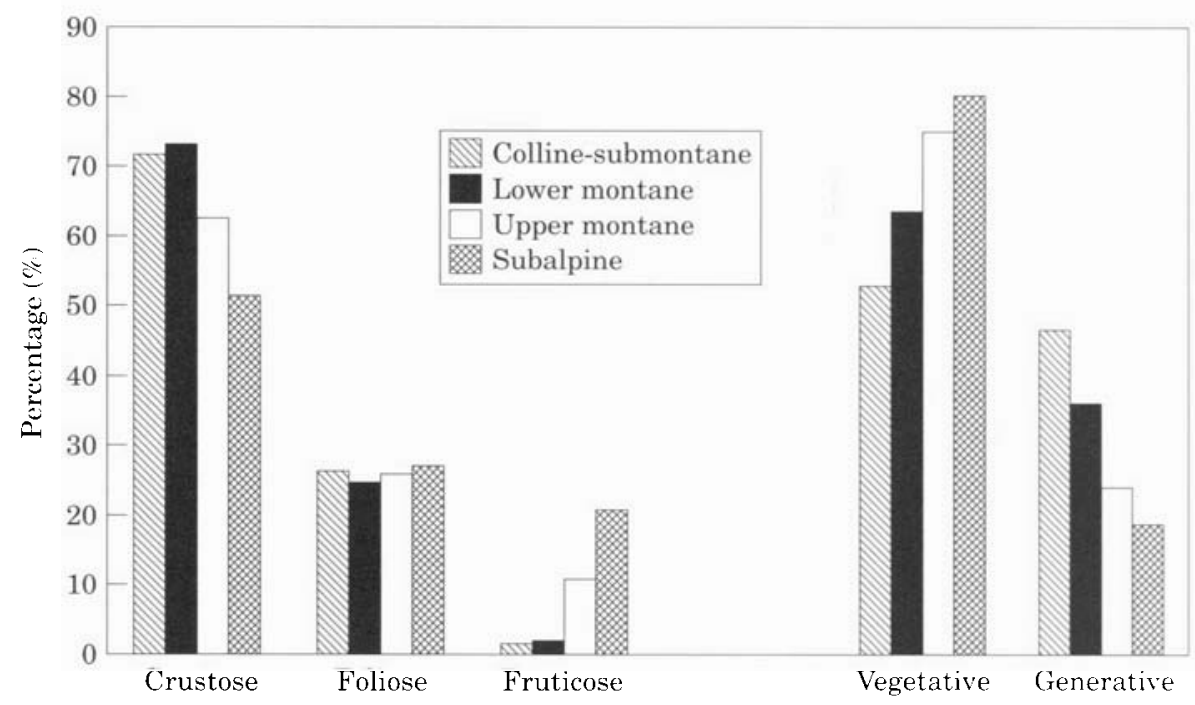

FIG. 5. Mean percentages per plot of crustose, foliose and fruticose lichens and of vegetative and generative dispersal type within the four vegetation belts.

the subalpine vegetation belt $(P \leqslant 0 \cdot 013)$. By distinguishing non-forest from forest in the four vegetation belts in the Pre-Alps, further differentiation is possible. Along the altitudinal gradient, forest plots in particular are responsible for the decrease in the importance of crustose lichens (Fig. 6), whereas in the colline-submontane belt the mean percentage per plot is extremely high $(93 \%)$. With every altitudinal step its decrease is significant $(P<0 \cdot 045)$. In non-forest the mean percentages in the four vegetation belts do not differ distinctly. In contrast, foliose lichens are of equal importance only if nonforest and forest are taken together. If separated, they show an opposite pattern of decrease and increase, although only the increase with every altitudinal step in forest areas is significant $(P<0 \cdot 05)$. Fruticose lichens show similar increases in non-forest and forest.

Concerning the types of dispersal, the altitudinal patterns described above are more marked in forest than in non-forest (Fig. 7). As a consequence, significant differences for every altitudinal step exist only for forest $(P \leqslant 0.05)$. The forest areas of the colline-submontane vegetation belt (Pre-Alps) are the only unit where the generative dispersal type reaches the same degree of importance as the vegetative one.

\section{Discussion}

\section{Frequency}

Inventories can provide important information for the conservation of organisms by indicating the existence of rare species, but also the abundance of common species. Beside the comparability of different mapping units, a necessarily representative inventory method should also support the 


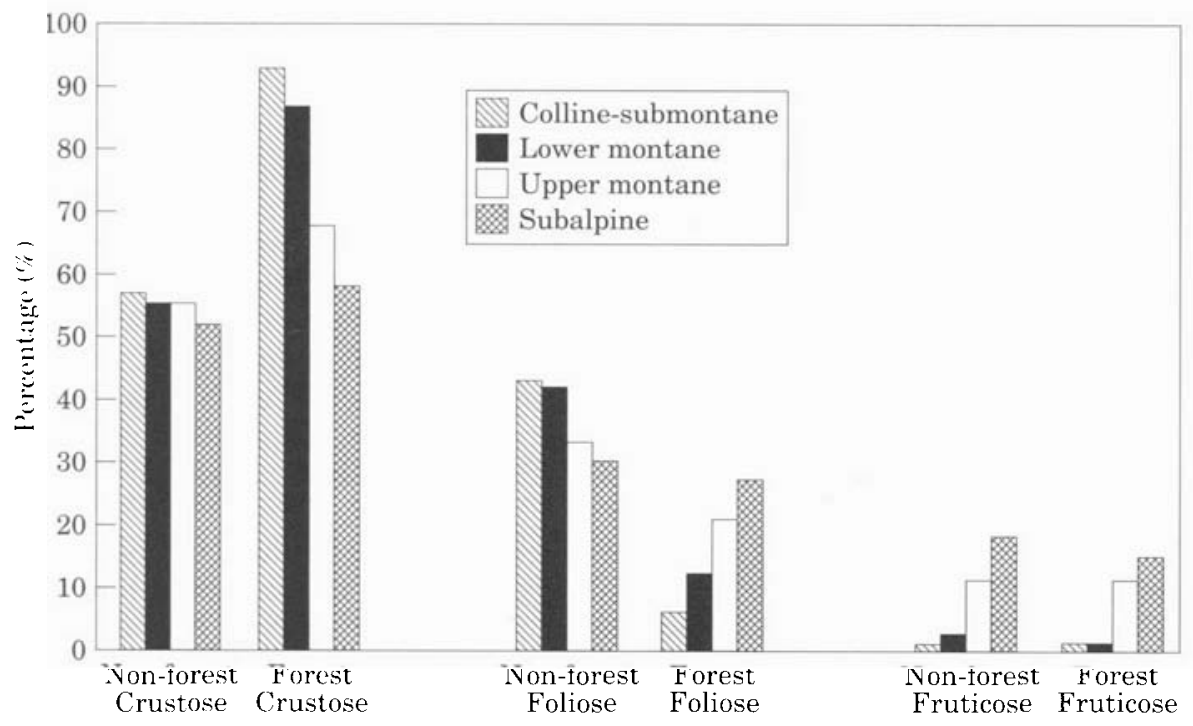

FIG. 6. Mean percentages per plot of crustose, foliose and fruticose lichens along the altitudinal gradient in the Pre-Alps, non-forest and forest strata separately.

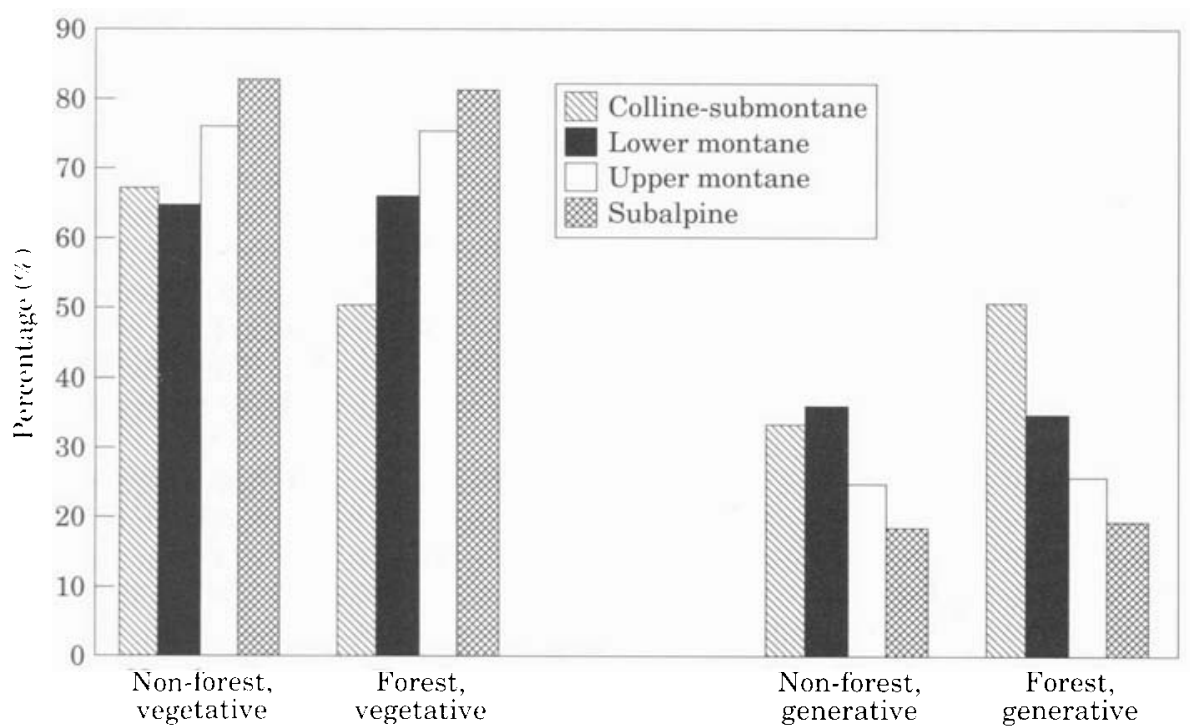

FIG. T. Mean percentages per plot of vegetative and generative dispersal type along the altitudinal gradient in the Pre-Alps, non-forest and forest strata separately.

comparability of species frequencies. As demonstrated by Urmi et al. (1990), traditional mapping, theoretically represented by herbaria specimens, underestimates the frequency of common species. A smallest scale programme, 
combined with random sampling and stratification, counteracts this bias. In this study stratification by region, vegetation formation and vegetation belt, and arbitrary plot choice without any preconceived bias, resulted in a frequency distribution of lichen species that corresponds almost entirely with the 'law of frequencies' (Raunkiaer 1934). A few species are very abundant, some show medium abundance and most are represented by only a few observations. In general, the observed log series model of species abundance is typical for situations where one or a few factors control the ecology (Magurran 1988). In contrast, the log normal distribution of species abundance, one of the most consistent phenomena in multi-species samples (Huston 1994), indicates the effect of many independent factors (May 1975). This model of species abundance was recently shown for foliicolous lichens in Costa Rica (Lücking 1994) and lichens on Salix caprea in Finland (Kuusinen 1994).

The same distribution of species frequencies in the regional interpretation units (study area, Central Plateau and Pre-Alps) led to the establishment of four classes of scarcity, each comprising $25 \%$ of the species. Just as within phanerogams and pteridophytes (Landolt 1991), species are often in danger of extinction in one region but more common in others and, as suggested by Clerc et al. (1992), cannot therefore be satisfactorily classified at national level only. Out of the 55 foliose and 25 fruticose species found in this study, 11 foliose and five fruticose species are listed in the provisional red data list of macrolichens of Switzerland (Clerc et al. 1992). Even if sampling size in the two regions was lower than 100, it is evident that Anaptychia ciliaris (on 3 plots) and Parmelia acetabulum (6) are at least not very rare in the Central Plateau, Leptogium saturnimum (3) and Menegazzia terebrata (3) are not very rare in the Pre-Alps. The proposed classification allows, for different interpretation units (sampling size $\geq 100$ ), the comparable assessment of scarcity of individual lichen species at different times. In this way it has been demonstrated that of the 13 lichens found for the first time in Switzerland (Dietrich \& Scheidegger 1996a), six are moderately common or common. Even among the seven undetermined sorediate crustose species, three seem to be common. Nevertheless, localities of very rare species may be revealed. This was the case with Cladonia incrassata, which was found growing at the base of a pine tree, for only the second time in Switzerland.

For the national survey of epiphytic lichens, the fact that frequency of common species will be estimated representatively by a representative plot choice will allow exclusion of those species not in danger of extinction at a regional or a national level. The quantitative criteria will be a lower threshold value of estimated absolute frequency for a given region (Jura, Central Plateau, Pre-Alps, Alps, Southern Alps) or the whole of Switzerland. This value has to be defined according to the international classification of extinction threats and, within certain confidence intervals, will separate at least those species with no risk of extinction.

\section{Diversity}

As no special priority was given to potentially rich habitats, the figures for species richness (262 epiphytic lichens for the entire study area, 134 for the 
Central Plateau and 243 for the Pre-Alps) are high. About 700 epiphytic species are estimated for the whole of Switzerland. Regional surveys in the Swiss Central Plateau and the Pre-Alps focusing on epiphytic lichens revealed considerably smaller species numbers (Camenzind \& Wildi 1991; Dietrich 1991; Groner 1990; Hilfiker 1989; Liebendörfer et al. 1991; Ruoss 1992; Scheidegger et al. 1991). Considering the restricted area of Glaubenberg, $42 \%$ of the expected epiphytic lichen flora of this country is found on only $2.3 \%$ of Switzerland's total area (c. 3\%o of the area below the timberline). In this small area, reliability of the sampling method is expressed by a species capture of $69 \%$ of the total epiphytic lichen flora by investigating the 40 plots. On average, $11 \%$ of the known flora of Glaubenberg was registered per plot.

Differences in $\alpha$-and $\beta$-diversity between different interpretation units have several origins. Here, only the most evident reasons are considered. The higher species richness in the Pre-Alps is due to the wider altitudinal range (in contrast to the Central Plateau, elevations above $800 \mathrm{~m}$ are also covered), and to the greater sampling intensity. Wohlgemuth (1993) demonstrated higher species numbers for pteridophytes and phanerogams in the Pre-Alps than in the Central Plateau, depending significantly on the range of altitude. If the Pre-Alps are divided into a lower and an upper part, each with the same sampling size as for the central Plateau, phorophyte diversity is far lower in the upper Pre-Alps than in the Central Plateau and the lower Pre-Alps. Nevertheless, overall species number and mean number per plot are distinctly higher. The high precipitation in this interpretation unit favours different lichen species, comparable to oceanic areas (Degelius 1935; Schauer 1965). Almost half of the species were restricted to this zone and were not found in the Central Plateau nor in the lower Pre-Alps. The dissimilarity of the lower Pre-Alps to the upper Pre-Alps is greater than that to the Central Plateau. Phorophyte diversity in forest and non-forest is almost the same. As a result of the lower trunk density in non-forest, more trees per plot were investigated in forest. Nevertheless, the measurements of lichen diversity in forest and non-forest, including the number of lichen species per plot, have almost equal values. The only clear difference is in $\beta$-diversity, reflecting the different species composition (each stratum having one third of its flora restricted to it).

Looking at vegetation belts, the high species richness in the upper montane belt is striking. With 160 species, more than $60 \%$ of the flora found in the study area occurs in this vegetation belt. The plot with the highest value of 49 species, representing almost $20 \%$ of the total flora investigated, was located in this belt, too. Beside the suboceanic climate of this belt, forests with low anthropogenic influence (such as forest management and air pollution) promote a rich lichen flora (Rose 1976; Selva 1994). In contrast to the subalpine belt with the lowest overall species richness, Fagus sylvatica and Abies alba are frequent tree species along with the dominant Picea abies. Frey (1958) demonstrated in a number of different areas in Switzerland that $F$. sylvatica and $A$. alba favour a richer lichen flora than $P$. abies. Here, the higher habitat diversity in terms of phorophyte species coincides well with the higher species richness (Kuusinen 1994; Lücking 1994). Nevertheless, the 
greater diversity of phorophyte species in colline-submontane and lower montane belts does not result in a higher lichen diversity compared to the upper montane belt. Detailed analysis of the lichen diversity of the different tree species are given in Dietrich \& Scheidegger (1996b).

The low total species number with a high number per plot in the subalpine belt might be compared to the conditions of arctic lichen vegetation, where the species number is relatively low but the number of individuals is high (Henssen \& Jahns 1973). In addition, the lichen flora of the subalpine belt shows easily the highest dissimilarity in forest as well as in non-forest. Increasing $\beta$-diversity with increasing altitudinal distance might be due mainly to larger climatic differences. Dissimilarity between forest and non-forest decreases markedly with every altitudinal step. This is due to the decreasing differences in phorophyte diversity.

\section{Ecological strategies}

Significant ranking of importance of different growth forms in terms of mean percentage per plot is the same in all strata. The higher percentage of fruticose lichens in the Pre-Alps compared to the Central Plateau is probably related to the higher precipitation, which supports intensive growth of this predominantly aerohygrophytic growth form. The greater light intensity at the lower tree trunk level in non-forest seems to be responsible for the higher percentage of foliose species per plot compared to forest. Higher air humidity in woodland seems to have a smaller effect on the importance of growth forms with a relatively large surface area. As foliose species are often competitive lichens with a high relative growth rate (Rogers 1990), their high mean percentage per plot in non-forest may be expected to result in lower diversity, as observed by Kuusinen (1994). Thus, species number per plot is slightly higher in non-forest. The decreasing importance of crustose growth forms with increasing altitude, especially in forest plots, could be influenced by decreasing ecological disturbance, as the more stress-tolerant crustose species showed the highest index of ruderality (Rogers 1990).

As an efficient adaptation to symbiotic life, vegetative reproduction in lichens is generally more abundant than generative reproduction (Henssen \& Jahns 1973). In the study area, vegetative dispersal was found to be of greater importance for every growth form. In addition, the mean percentage per plot of lichens with vegetative dispersal was significantly higher. As Frey (1958) observed, recolonization of lichens by symbiotic diaspores in clear-cut secondgrowth forests from adjacent woodland takes a long time. Therefore, as the mean percentage of species with vegetative dispersal per plot is significantly higher in forest and non-forest, it is still more efficient than generative propagation.

As a methodological study, this work was aimed at contributing to the design of the national survey of epiphytic lichens. Standardized data sampling on the intersection points of the $1 \times 1 \mathrm{~km}$ grid of the Swiss coordinate system have shown to be an appropriate tool for the evaluation of lichen diversity. From 1996 to 1999 slightly modified sampling will be used to collect data on 826 plots in the whole of Switzerland. Plot choice will be representative according to the strata of the region, vegetation formation and vegetation belt. 
Within every stratum plots will be determined at random. Designed as long-term ecological observation, the national standardized survey will provide representative data on lichen frequency in order to facilitate the compilation of a new Red List of epiphytic lichens.

Our sincerest thanks go to Dr B. Coppins (Edinburgh) for determination of crustose lichens and to Dr T. Tonsberg (Bergen) for giving us access to material for comparison of sorediate crustose lichens from Herbar BG. Dr P. Brassel, M. Frei, Dr S. Ghosh, Dr U. Groner and Dr T. Wohlgemuth (Birmensdorf) are gratefully acknowledged for placing useful data at our disposal and stimulating discussions. The authors thank J. Purnell (Basel) for correcting the English text and the reviewers for important suggestions and improvements. We are grateful to the Sw iss National Science Foundation (Project No. 31-32567.91) and the BUWAL (Bundesamt für Umwelt, Wald und Iandschaft; WSL Project No. 6.94.900) for financial support.

\section{REFERENCES}

Bundesamt für Statistik (ed.) (1980) Informationsraster Benützerhandbuch. Arbeitsdokumente schweizerische Statistik (Bern) H. 3.

Camenzind, R. \& Wildi, E. (1991) Die epiphytische Flechtenflora des GurnigelGantrischgebietes (BE). Botanica Helvetica 101: 183-197.

Clerc, P. \& Scheidegger, C. (1990) Lichen mapping in Switzerland: the epiphytic lichens of the Plateau and the Prealps. Stuttgarter Beiträge zur Naturkunde Ser. A 456: 73-77.

Clerc, P., Scheidegger, C. \& Ammann, K. (1992) Liste rouge des macrolichens de la Suisse. Botanica Helvetica 102: $71 \cdot-83$.

Degelius, G. (1935) Das ozeanische Element der Laub- und Strauchflechtenflora von Skandinavien. Acta Phytogeographia Suecica 7: 1-411.

Dietrich, M. (1991) Die Flechtenflora des Merliwaldes, Giswil/OW (Zentralschweiz). Botanica Helietica 101: 167-182.

Dietrich, M. \& Scheidegger, C. (1996a) The importance of sorediate crustose lichens in the epiphytic lichen flora of the Swiss Plateau and the Pre-Alps. Lichenologist 28: 245-256.

Dietrich, M. \& Scheidegger, C. (1996b) Diversität und Zeigerwerte von epiphytischen Flechten der häufigsten Baumarten: Ein methodischer Ansatz zur Beurteilung von Umweltveränderungen im Wald und im Freiland. Botanica Helvetica 106: 85-102.

EAFV (Eidg. Anstalt für das forstliche Versuchswesen) (1988) Schweizerisches Landesforstinventar: Ergebnisse der Erstaufnahmen 1982-1986. Berichte der Eidgenössischen Anstalt für das forstliche Versuchswesen 305: 1-375.

Frey, E. (1958) Dic anthropogenen Einflüsse auf die Flechtenflora und -vegetation in verschiedenen Gebieten der Schweiz. Ein Beitrag zum Problem der Ausbreitung und Wanderung der Flechten. Veröfentlichungen des Geobotanischen Institutes Rübel, ETH Zürich 33: $91-107$.

Groner, L. (1990) Die epiphytischen Makroflechten in Bödmerenwaldgebiet, Muotatal SZ. Ber. Berichte der Schavzerischen Naturforschenden Gesellschaft 9: 77-93.

Henssen, A. \& Jahns, H. M. (1973) ['1974'] Lichenes. Stuttgart: G. Thieme.

Herzig, R. \& Urech, M. (1991) Flechten als Bioindikatoren: Integriertes biologisches Messsystem der Lufte'ershmutzung fïr das Schaveizer Mittelland. Berlin: Cramer.

Hilfiker, H. (1989) Strauch- und Blattflechten am Immenberg. Mitteilungen der Thurgauischen Vatuforschenden Gesellschaft, Beiheft 2: 63-77.

Huston, M. A. (1994) Biological Dizersity. Cambridge: Cambridge University Press.

Kuusinen, M. (1994) Epiphytic lichen flora and diversity on Salix caprea in old-growth southern and middle boreal forests of Finland. Annales Botanici Fennici 31: 77-92.

Landolt, E. (1991) Gefährdung der Fam- und Blätenpflanzen in der Schweiz. Bern: BUWAL.

Licbendörfer, L. Keller, C. \& Urech, M. (1991) Dauerbeobachtung von Flechten in Waldgebieten des Kantons Aargau. Mitteilungen der Aargauischen Naturforschenden Gesellschaft 23: 113-152.

Lücking, R. (1994) Folikole Flechten und ihre Mikrohabitatspräferenzen in einem tropischen Regenaiald in Costa Rica. Doctoral Thesis, University Ulm.

Magurran, A. E. (1988) Ecological Diversity and its Measurement. Princeton: Princeton University Press. 
May, R. M. (1975) Patterns of species abundance and diversity. In Ecology and Evolution of Communities (M. L. Cody \& J. M. Diamond, eds): 81-120. Harvard: Belknap Press.

Nimis, P. L., Lazzarin, G. \& Gasparo, D. (1991) Lichens as bioindicators of air pollution by $\mathrm{SO}_{2}$ in the Veneto region (NE Italy). Studia Geobotanica 11: 3-76.

Raunkiaer, C. (1934) The Life Forms of Plants and Statistical Plant Geography. Oxford: Clarendon Press.

Rogers, R. W. (1990) Ecological strategies of lichens. Lichenologist 22: 149-162.

Rose, F. (1976) Lichenological indicators of age and environmental continuity in woodlands. In Lichenology: Progress and Problems (D. H. Brown, D. L. Hawksworth \& R. H. Bailey, eds). 279-307. London: Academic Press.

Ruoss, E. (1992) Flechten im Kanton Luzern. Untersuchungen zur Bioindikation und Floristik, sowie zur Immissionsökologie voralpiner Hochmoore. Veröffentlichungen aus dem Natur-Museum Luzern 3: 1-98.

Schauer, T. (1965) Ozeanische Flechten im Nordalpenraum. Portugaliae Acta Biologica (B) 8: $17-299$

Scheidegger, C., Dietrich, M., Frei, M., Keller, C., Kuhn, N. \& Wildi, E. (1991) Zur Waldflechtenflora des westlichen Aargauer Mittellandes und ihrem Wandel seit 1960. Mitteilungen der Aargauischen Naturforschenden Gesellschaft 23: 175-191.

Selva, S. B. (1994) Lichen diversity and stand continuity in the northern hardwoods and Spruce-Fir forests of northern New England and western New Brunswick. Bryologist 97: $424-429$.

Thor, G. (1995) Red Lists-aspects of their compilation and use in lichen conservation. Mitteilungen der Eidgenössischen Forschungsanstalt für Wald, Schnee und Landschaft 70: 29-39.

Tonsberg, T. (1992) The sorediate and isidiate, corticolous, crustose lichens in Norway. Sommerfeltia 14: 1-331.

Urmi, E., Schnyder, N. \& Geissler, P. (1990) A new method in floristic mapping as applied to an inventory of Swiss bryophytes. In Vegetation and flora of temperate zones (U. Bohn \& R. Neuhäusl eds): 21-32. The Hague: Academic Publishing.

Welten, M. \& Sutter, R. (1982) Verbreitungsatlas der Fam-und Blütenpflanzen der Schweiz. Basel Birkhäuser.

Wirth, V. (1992) Zeigerwerte von Flechten. Scripta Geobotanica 18: 215-237.

Wohlgemuth, T. (1993) Der Verbreitungsatlas der Farn- und Blütenpflanzen der Schweiz (Welten und Sutter 1982) auf EDV: Die Artenzahlen und ihre Abhängigikeit von verschiedenen Faktoren. Botanica Helvetica 103: 55-71. 